\title{
MANAGEMENT OF ZUCCHINI YELLOW MOSAIC VIRUS IN CUCUMBER THROUGH GENETIC AND SALICYLIC ACID INDUCED RESISTANCE
}

\author{
Ummad-ud-Din Umar ${ }^{1, *}$, Syed Atif Hasan Naqvi', Azhar Ali Khan², Samiya Mehmood Khan', \\ Ateeq-ur-Rehman', Rashida Perveen', and Muhammad Ejaz-ul-Haq ${ }^{1}$ \\ ${ }^{1}$ Department of Plant Pathology, Faculty of Agricultural Sciences and Technology, Bahauddin Zakariya University, \\ Multan-60000, Pakistan; ${ }^{2}$ Pakistan Agricultural Research Council, Research \& Training Station, Bahauddin \\ Zakariya University, Multan, Pakistan. \\ *Corresponding author's e-mail: atifhasanshah@hotmail.com
}

\begin{abstract}
Zucchini yellow mosaic virus (ZYMV) is among the most destructive pathogen of vegetable crops and causing enormous losses specifically to cucumber. Twenty varieties/ lines were evaluated for their resistance against ZYMV under field and controlled conditions. The disease severity data was calculated through disease rating scale and confirmed with ELISA. Scarcity of genetic resistance was observed in cucumber against ZYMV as only one variety Beit-alpha was appeared to be resistant with 6 and $6.67 \%$ disease severity under controlled and field conditions, respectively. To mitigate the ZYMV infection, Salicylic acid (SA) was exogenously applied at different concentration viz., $0.01,0.1,1$ and $10 \mathrm{mM}$ for the induction of resistance in cucumber plants. The resultant increase in the phenolic and protein contents was estimated whereas virus concentrations were determined by ELISA. The exogenous application of SA significantly increased the phenolic and protein contents as compared to control. Virus multiplication appeared to be inhibited at $10 \mathrm{mM}$ concentration of SA. This study showed that exogenously applied SA could offer a good source for the management of ZYMV by inducing resistance in cucumber.
\end{abstract}

Keywords: Cucumis sativus, ELISA, phenol, proteins, plant resistance

\section{INTRODUCTION}

Cucumber (Cucumis sativus L.) is the most widely growing vegetable crop. It is an important crop of Pakistan, cultivated on an area of 3397 ha with a total production of 142876 tonnes (Anonymous, 2013). In the country although cucumber is cultivated as the major vine crop but its production is much lower due to certain viral, nematode and fungal diseases. Cucurbits are attacked by several viruses. Cucumber mosaic virus (CMV), Squash mosaic virus (SqMV) and Zucchini yellow mosaic virus (ZYMV) are most destructive viruses among the others (Ashfaq et al., 2015; Svoboda et al., 2013). ZYMV is transmitted in a non-persistent manner by approximately 60 species of aphid especially Aphis gossypii, Myzus persicae (Francki et al., 1979). This virus can also be transmitted mechanically but not through seed (Dodds et al., 1984). Leaves show symptoms as deformation, severe mosaic, blistering, and reduced size. On infected fruits uneven skin coloring and prominent deformation appear. Most important control strategies for ZYMV include sowing the resistant varieties; remove the virus vectors by insecticides and destroying the alternate hosts of pathogen through herbicides (Provvidenti, 1993). Mainly commercial cucumber varieties/lines are susceptible to ZYMV.

Plants are exposed to different stimuli in response to changes in the environmental conditions including drought, low temperature salinity stresses and pathogens attack. In plants,
SA performs an important role in the form of defense response, ripening of fruits, development and the regulation of plant growth (Miura and Tada, 2014). Defense mechanism of plant activates in response of pathogen attack and the elicitors are compounds which stimulate the chemical defense system in plants. Different biosynthesis pathways are activated in treated plants depending on the compound used. Usually tested chemical elicitors are salicylic acid, methyl salicylate, benzothiadiazole, benzoic acid, chitosan etc., which act as signalling molecules and produce the phenolic compounds that results in the activation of various defenserelated enzymes in plants (Thakur and Sohal, 2013). There are several natural phenomenons in plants to produce the resistance against different pathogens. In plants many chemicals induce the resistance (Uta et al., 2005), among them salicylic acid (SA) is one of the key components of defense signal transduction which induce a full set of local and systemic acquired resistance (SAR) gene. It is naturally present in plants and plays very important role in SAR activation that conferring resistance to different pathogens. Function of SA between plant and pathogen interaction has been extensively studied. When pathogens attack on host plants, the defence system activates the SAR gene (Anand $e t$ al., 2008; Halim et al., 2006; Maleck et al., 2000). SA increases the phenolic compounds that have ability to interfere and enhance the resistance against pathogen (Vimala and Suriachandraselvan, 2009). SA also increases the 
pathogen-related proteins which have antimicrobial activity and thus increase the resistance against viral diseases (Huijsduijnen et al., 1986).

The present research work was aimed with firm attitude to identify the sources of genetic resistance in cucumber germplasm against ZYMV and the application of SA for the suppression of virus and to estimate total proteins and phenolic contents produced in response of activated systemic resistance against ZYMV in cucumber plants.

\section{MATERIALS AND METHODS}

\section{Evaluation of resistance:}

Planting material: The experiment was performed at research area of Department of Plant Pathology in Bahuddin Zakariya University, Multan. The seeds of twenty cucumber lines/ varieties were collected from different research institutes and local markets of Pakistan.

Under field condition: The soil was well prepared for sowing the seeds of different varieties/ lines. The experiment was conducted in a randomized complete block design (RCBD), plot was divided into three 3 blocks and twenty varieties were randomized in each block. Row to row distance was $10 \mathrm{~cm}$ while plant to plant distance was maintained $30-35 \mathrm{~cm}$ and the spacing between beds was 2 feet. After 3 rows of each test line, single row of local susceptible check was planted to serve as a spreader of ZYMV. Water was irrigated after four days and other agronomic practices were also adopted.

Under control condition: All varieties/ lines were sown in the mixture of sand, clay and FYM in earthen pots using CRD (complete randomize design). Virus inoculum was prepared in $0.02 \mathrm{M}$ phosphate-buffer ( $\mathrm{pH} \mathrm{7.4)}$ by grinding virusinfected leaves samples $(1: 5 \mathrm{w} / \mathrm{v})$ in pestle and mortar. At two leaves stage, carborundum powder (6000 mesh, BDH, Germany) was dusted on young seedlings and inoculum was applied with the help of cotton swab on the leaves. All inoculated plants were washed with water.

Disease assessment: The disease severity index on each variety was assessed by percent plant infection that was calculated by the disease rating scale and formula devised by $\mathrm{Xu}$ et al. (2004) (Table 1). Whereas the disease severity on each variety/ line was also backed-up by DAS-ELISA for conformation and estimation of virus titre. Both results helped in assessing the level of resistance of cucumber varieties/lines against ZYMV.

Disease severity index $=\frac{\text { Sum of all numerical scores }}{\text { Total no.of observations }} \times 100$

(Xu et al., 2004)

Induction of resistance: Highly susceptible variety 40 days Pak was sown in mixture of sand, clay and FYM in plastic pots (15 cm in diameter) in glass house where temperature was maintained between 25 and $29^{\circ} \mathrm{C}$. After 22 days of sowing, plants were divided into four groups and a total of ten treatments replicated thrice were applied in a systematic way. The treatment groups are given as under;

Group-1: S.A Sprayed with 0.01, 0.1, 1.0 and $10 \mathrm{mM} \mathrm{SA}$ without viral inoculum

Group-2: S.A+ ZYMV (Pre-treated with 0.01, 0.1, 1.0 and $10 \mathrm{mM}$ of SA and inoculated with ZYMV three days later)

Group-3: Plants inoculated with ZYMV at the same time as other tested group

Group-4: Healthy control, sprayed with distilled water.

ZYMV was mechanically inoculated after three days of S.A application. Virus infected leaves sample of $1 \mathrm{~g}$ was crushed in $5 \mathrm{ml}$ pre chilled phosphate buffer at $\mathrm{pH} 7.4$ with the help of pestle and mortar. Homogenate mixture was filtered through muslin cloth. Before applying the viral inoculum, leaves were dusted with carborandum powder. After 22 days of inoculation youngest fully developed leaves from both treated and control were collected for ELISA test.

ZYMV detection by DAS-ELISA: DAS-ELISA technique (Clark and Adam, 1977) was used to detect ZYMV with antibodies provided by Agdia Inc. USA. Microtitre plate was coated with capture antibody and incubated overnight. Antigen was extracted from the leaf tissues, $100 \mu \mathrm{l}$ was loaded in each well of the plate and incubated overnight. After washings plate was coated with enzyme conjugate and incubated at room temperature. Plate was coated with buffer containing $\mathrm{pNpp}$ at the rate of $1 \mathrm{mg} / \mathrm{ml}$ and incubated for 30 minutes. The virus titre was measured on a plate reader (Bio Tek, ELx 800) at $405 \mathrm{~nm}$.

Estimation of phenolic contents: Samples were collected from cucumber plants kept in ice box and brought to laboratory to determine the total phenolic contents. Total phenolic contents were determined by using the Folin Ciocalteau (FC) reagent method (Bray and Thorpe, 1954).

Table 1. Disease rating scale for the assessment of ZYMV.

\begin{tabular}{llll}
\hline Index & Description of symptoms & Infection \% & Host reaction \\
\hline 0 & No symptoms. & 0 & $* \mathrm{HR}$ \\
1 & Slightly mosaic on leaves. & $<10 \%$ & $* \mathrm{R}$ \\
2 & Mosaic patches and/or necrotic spots on leaves. & $<20 \%$ & $* \mathrm{MR}$ \\
3 & Leaves near apical meristem deformed slightly, yellow and reduced in size. & $<40 \%$ & $* \mathrm{MS}$ \\
4 & Apical meristem with mosaic and deformation & $<60 \%$ & $* \mathrm{~S}$ \\
5 & Extensive mosaic and serious deformation of leaves or plant dead & $>70-100 \%$ & $* \mathrm{HS}$ \\
\hline
\end{tabular}

$* \mathrm{R}=$ Resistance, $* \mathrm{MR}=$ moderately resistance, $* \mathrm{MS}=$ moderately susceptible, $* \mathrm{~S}=$ Susceptible, $* \mathrm{HS}=$ highly susceptible. 
Solution of $100 \mathrm{mg}$ pure Gallic acid was dissolved in one litre of water to prepare a standard stock solution to estimate standard curve. One gram of leaf sample was homogenized in $5 \mathrm{ml}$ of $70 \%$ ethanol and centrifuged at $14000 \mathrm{rpm}$ for 15 minutes at $4{ }^{\circ} \mathrm{C} .1 \mathrm{ml}$ of supernatant was added in each test tube followed by $5 \mathrm{ml}$ of diluted FC reagent and filtered through Whatman paper No.1. $4 \mathrm{ml}$ of $7.50 \%$ sodium carbonate solution was added in tubes and kept for 2 hours away from strong light at room temperature. Colour intensity was observed at $765 \mathrm{~nm}$ by using a spectrophotometer (UV 300, ORI, Germany). The phenolic contents were calculated by standard curve equation.

Estimation of total proteins: The Bradford assay (Bradford, 1976) is a protein determination method that involves the binding of Coomassie Brilliant Blue G-250 dye with proteins. Bovine Serum Albumin, (BSA), (Bio Basic. Inc. Ca.) was dissolved in distilled water with concentrations ranging from $10 \mu \mathrm{g} / 100 \mu \mathrm{l}$ to $100 \mu \mathrm{g} / 100 \mu \mathrm{l}$ for standard curve estimations. Coomassie Brilliant Blue G250 (100 mg) was dissolved in $50 \mathrm{ml} 95 \%$ ethanol and $100 \mathrm{ml} 85 \%(\mathrm{w} / \mathrm{v})$ phosphoric acid. The solution was diluted to 1 litter and filtered through Whatman filter paper No. 1. One $\mathrm{ml}$ of Bradford reagent and $20 \mu \mathrm{l}$ of sample to be quantified were mixed in clean cuvettes. After five minutes absorbance readings were taken by spectrophotometer at $595 \mathrm{~nm}$ and total protein contents were calculated by standard curve equation.

Statistical analysis: The collected data was analyzed statistically and subjected to analysis of variance (ANOVA) and treatments mean were compared by the least significant difference test $(\mathrm{LSD})$ at $(P \leq 0.05)$ for the ELISA $\left(\mathrm{OD}_{405 \mathrm{~nm}}\right)$ values, phenolic contents and total proteins under controlled conditions. Duncan's Multiple Range (DMR) test was applied for multiple mean comparisons at $(P \leq 0.05)$ to determine the disease severity index in field experiment by using the SAS (Statistical software package 8.0 Institute Carry Inc; USA).

\section{RESULTS}

Response of cucumber varieties/lines to Zucchini yellow mosaic virus: Out of twenty varieties/ lines Beit-Alpha variety showed resistant response against ZYMV in both field and controlled conditions with the disease severity index $6 \%$

Table 2. Response of varieties/lines against $Z Y M V$, disease severity (DS) index and ELISA values (OD $405 \mathrm{~nm})$.

\begin{tabular}{|c|c|c|c|c|c|c|c|}
\hline \multirow{2}{*}{$\begin{array}{l}\text { S. } \\
\text { No. }\end{array}$} & \multirow[t]{2}{*}{ Variety } & \multicolumn{3}{|c|}{ Under glasshouse conditions \pm S.E* } & \multicolumn{3}{|c|}{ Under field conditions \pm S.E* } \\
\hline & & $\begin{array}{c}\text { Disease severity } \\
(\%)\end{array}$ & $\begin{array}{c}\text { Virus } \\
\text { concentration }\end{array}$ & Response & $\begin{array}{c}\text { Disease severity } \\
(\%)\end{array}$ & $\begin{array}{c}\text { Virus } \\
\text { concentration }\end{array}$ & Response \\
\hline 1 & Beit-alpha & $6.67 \mathrm{gf}( \pm 2.19)$ & 0.07 e $( \pm 0.02)$ & $\mathrm{R}^{*}$ & $6.00 \mathrm{i}( \pm 1.15)$ & $0.07 \mathrm{e}( \pm 0.03)$ & $\mathrm{R}^{*}$ \\
\hline 2 & Captin & 11.33 gf $( \pm 1.15)$ & $0.15 \mathrm{de}( \pm 0.03)$ & $\mathrm{MR}^{*}$ & $11.33 \mathrm{ih}( \pm 0.88)$ & $0.13 \mathrm{c}-\mathrm{e}( \pm 0.01)$ & $\mathrm{MR} *$ \\
\hline 3 & Green super & $11.33 \mathrm{gf}( \pm 0.33)$ & 0.19 de $( \pm 0.03)$ & MR & 11.26 ih $( \pm 1.27)$ & $0.14 \mathrm{~b}-\mathrm{e}( \pm 0.01)$ & MR \\
\hline 4 & Anmol & $13.33 \mathrm{f}( \pm 0.33)$ & 0.23 d-e $( \pm 0.02)$ & MR & 11.00 ih $( \pm 1.15)$ & $0.15 \mathrm{~b}-\mathrm{e}( \pm 0.02)$ & MR \\
\hline 5 & Durga & 28.67 e $( \pm 3.67)$ & 0.27 de $( \pm 0.33)$ & MS* & $11.00 \mathrm{ih}( \pm 0.58)$ & 0.15 de $( \pm 0.02)$ & MR \\
\hline 6 & Waqas & $39.67 \mathrm{~d}( \pm 3.18)$ & 0.65 b-e $( \pm 0.42)$ & MS & 11.00 ih $( \pm 1.15)$ & $0.15 \mathrm{~b}-\mathrm{e}( \pm 0.01)$ & MR \\
\hline 7 & Market more 76 & $44.00 \mathrm{~d}( \pm 0.58)$ & $0.27 \mathrm{de}( \pm 0.14)$ & $\mathrm{S}^{*}$ & 11.00 ih $( \pm 1.15)$ & 0.16 de $( \pm 0.03)$ & MR \\
\hline 8 & Akbar & $45.00 \mathrm{~d}( \pm 0.58)$ & $0.26 \mathrm{de}( \pm 0.01)$ & $\mathrm{S}$ & 11.00 ih $( \pm 0.58)$ & $0.11 \mathrm{~d}-\mathrm{e}( \pm 0.01)$ & MR \\
\hline 9 & Cucumber F1 Babu & $45.33 \mathrm{~d}( \pm 0.88)$ & $0.28 \mathrm{de}( \pm 0.06)$ & $\mathrm{S}$ & $12.00 \mathrm{~h}( \pm 0.58)$ & 0.18 de $( \pm 0.03)$ & MR \\
\hline 10 & F1 hybrid bilal & 59.33 c $( \pm 0.67)$ & $0.41 \mathrm{c}-\mathrm{e}( \pm 0.19)$ & $\mathrm{S}$ & 20.33 de $( \pm 0.88)$ & $0.20 \mathrm{~b}-\mathrm{e}( \pm 0.06)$ & MR \\
\hline 11 & Baran- 180 & $65.33 \mathrm{bc}( \pm 5.46)$ & 0.68 b-e $( \pm 0.19)$ & HS $*$ & $41.00 \mathrm{~g}( \pm 0.58)$ & $0.24 \mathrm{de}( \pm 0.06)$ & MS* \\
\hline 12 & Local kheera & $69.00 \mathrm{a}( \pm 0.58)$ & 0.82 b-e $( \pm 0.40)$ & HS & 59.33 de $( \pm 0.33)$ & 0.53 d-e $( \pm 0.41)$ & $\mathrm{S}^{*}$ \\
\hline 13 & SR Seed & $67.33 \mathrm{~b}( \pm 0.88)$ & 0.90 b-e $( \pm 0.73)$ & HS & 59.00 de $( \pm 5.77)$ & 0.54 d-e $( \pm 0.40)$ & $\mathrm{S}$ \\
\hline 14 & Cucumber F1 & $67.00 \mathrm{~b}( \pm 2.89)$ & 0.94 b-e $( \pm 0.39)$ & HS & 57.66 e $( \pm 1.76)$ & 0.77 b-e $( \pm 0.60)$ & $\mathrm{S}$ \\
\hline 15 & Malaga F1 & $67.67 \mathrm{~b}( \pm 0.88)$ & 0.96 de $( \pm 0.08)$ & HS & 51.33 f $( \pm 0.88)$ & 0.49 bc $( \pm 0.31)$ & $\mathrm{S}$ \\
\hline 16 & $227-\mathrm{G}$ & $80.00 \mathrm{a}( \pm 1.15)$ & $1.35 \mathrm{bc}( \pm 0.34)$ & HS & $63.33 \mathrm{~cd}( \pm 0.67)$ & $1.54 \mathrm{ab}( \pm 0.40)$ & HS* \\
\hline 17 & Cucumber 6363 & 80.33 a $( \pm 1.20)$ & $1.11 \mathrm{~b}-\mathrm{d}( \pm 0.14)$ & HS & $67.00 \mathrm{c}( \pm 0.58)$ & 0.73 de $( \pm 0.28)$ & HS \\
\hline 18 & Proline & 79.33 a $( \pm 0.33)$ & $1.34 \mathrm{bc}( \pm 0.52)$ & HS & $76.66 \mathrm{~b}( \pm 0.88)$ & $1.14 \mathrm{bc}( \pm 0.38)$ & HS \\
\hline 19 & Denar022F1 & 78.00 a $( \pm 0.58)$ & 1.06 b-e $( \pm 0.43)$ & HS & $79.66 \mathrm{ab}( \pm 0.67)$ & $1.11 \mathrm{~b}-\mathrm{e}( \pm 0.05)$ & HS \\
\hline 20 & 40 days Pak & 80.00 a $( \pm 0.58)$ & $2.27 \mathrm{a}( \pm 0.52)$ & HS & $82.00 \mathrm{a}( \pm 0.58)$ & $2.09 \mathrm{a}( \pm 0.10)$ & HS \\
\hline 21 & +ive Control & --- & $1.50 \mathrm{ab}( \pm 0.12)$ & --- & --- & $1.95 \mathrm{ab}( \pm 0.04)$ & --- \\
\hline 22 & -ive Control & --- & $0.24 \mathrm{de}( \pm 0.23)$ & --- & --- & 0.13 de $( \pm 0.02)$ & --- \\
\hline \multirow[t]{2}{*}{23} & Healthy & --- & $0.26 \mathrm{de}( \pm 0.01)$ & --- & --- & $0.11 \mathrm{de}( \pm 0.05)$ & --- \\
\hline & LSD* & 1.78 & 0.23 & --- & 4.60 & 0.65 & --- \\
\hline
\end{tabular}

Means followed by same letter in each column are not statistically different at $(P>0.05)$; *S.E $=\mathrm{Standard}$ error, *LSD= Least significant difference, $* \mathrm{R}=$ resistant, $* \mathrm{MR}=$ moderately resistant, $* \mathrm{MS}=$ moderately susceptible, $* \mathrm{HS}=$ highly susceptible 
and ELISA (OD $405 \mathrm{~nm}$ ) value was 0.07 (Table 2). F1 hybrid Bilal, Baran- 180, Local kheera, Akbar, Cucumber F1, Captin, Malaga F1, Market more 76 and SR Seed were moderately resistant in controlled condition with the disease severity ranged between 11 to $12.33 \%$. However, in field condition three varieties Captain, Green super and Anmol were appeared to be moderately resistant under field. Durga was moderately susceptible to ZYMV in controlled and field conditions. Waqas variety was moderately susceptible in field conditions. Cucumber F1 Babu is susceptible in both control and field conditions. Three varieties/ lines Anmol, Denor 022 F1 and $227 \mathrm{G}$ were susceptible in controlled conditions. While three varieties Market more, Akbar and F1 hybrid Bilal were susceptible in the field conditions. Two varieties/ lines Waqas and Green super were highly susceptible in the controlled conditions. Baran-180, Local khera, SR Seed, Cucumber F1, Malaga F1, 277-G and Denar 022 F1 were highly susceptible in field condition. Three varieties 40 days Pak, Proline and Cucumber 6363 were found highly susceptible in controlled and field conditions where maximum disease severity was observed 82, 76.66 and $63.33 \%$, respectively, in controlled condition whereas 80 , 79.33 and $80.33 \%$, respectively, in field condition while ELISA values were 2.09, 1.14 and 1.54, respectively, in controlled condition whereas in field the values were observed 2.27, 1.34 and 1.11, respectively.

Induction of resistance: After 22 days of inoculation symptoms appeared on cucumber leaves as compared to healthy leaves. Symptoms were more prominent in new leaves than fully expanded older leaves. These symptoms were suppressed when SA was applied as foliar agent. Symptoms of ZYMV appeared in inoculated leaves when pretreated with $0.01 \mathrm{mM}, 0.1 \mathrm{mM}$ and $1 \mathrm{mM}$ concentration of SA but when treated with $10 \mathrm{mM}$ SA the virus was not detected as the ELISA OD value was only 0.08 (Table 3).

Table 3. Effect of salicylic acid treatments on ZYMV titre and disease severity on cucumber leaves

\begin{tabular}{lcc}
\hline Treatments & $\begin{array}{c}\text { Virus Conc. } \\
\mathbf{\pm S . E}\end{array}$ & $\begin{array}{c}\text { Disease Severity } \\
\boldsymbol{\%} \pm \mathbf{S . E}\end{array}$ \\
\hline $0.01 \mathrm{mM} \mathrm{SA}+$ Virus & $1.01 \pm 0.41 \mathrm{ab}$ & $76 \pm 0.321 \mathrm{~b}$ \\
$0.1 \mathrm{mM}$ SA + Virus & $1.76 \pm 0.49 \mathrm{a}$ & $81 \pm 1.15 \mathrm{ab}$ \\
$1 \mathrm{mM}$ SA + Virus & $0.85 \pm 0.60 \mathrm{ab}$ & $55 \pm 1.53 \mathrm{c}$ \\
$10 \mathrm{mM}$ SA + Virus & $0.08 \pm 0.03 \mathrm{~b}$ & $2 \pm 0.33 \mathrm{~d}$ \\
Infected & $1.40 \pm 0.11 \mathrm{ab}$ & $85 \pm 0.58 \mathrm{a}$ \\
Healthy & $0.14 \pm 0.06 \mathrm{~b}$ & $0 \pm 0.00 \mathrm{e}$ \\
LSD* & 1.39 & 5.33 \\
\hline
\end{tabular}

Values with the same letter in the columns are not statistically different, $*$ LSD $=$ Least significant difference

When cucumber plants were treated with SA at $0.01 \mathrm{mM}, 0.1$ $\mathrm{mM}$ and $1 \mathrm{mM}$ concentrations, the virus titre was gradually decreased as the OD values were 1.01, 1.76 and 0.86, respectively and severity of the disease was also decreased.
Phenolic contents: Total phenolic contents were increased significantly in cucumber plants treated with SA as compared to control (Fig. 1). Maximum phenolic contents were produced when SA applied at $10 \mathrm{mM}$ concentration i.e. $220.14 \mathrm{mg} / \mathrm{g}$ while minimum phenolic compounds were produced at $0.1 \mathrm{mM}$ SA concentration. However, in second group where SA applied after three days of virus inoculations maximum phenolic contents were $185.86 \mathrm{mg} / \mathrm{g}$ produced at $10 \mathrm{mM}$ SA concentration while in this group minimum phenolic contents i.e., $59.19 \mathrm{mg} / \mathrm{g}$ were observed at $0.01 \mathrm{mM}$ concentration of SA.

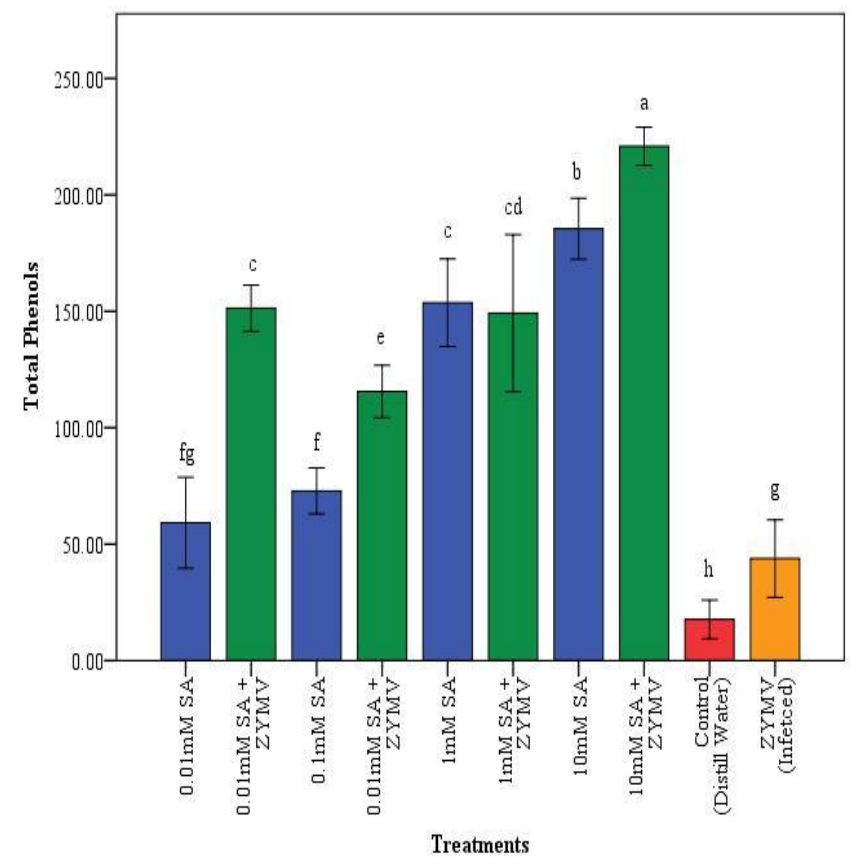

Figure 1. Effect of SA and ZYMV infection on phenolic contents (mg/g fresh wt.) of cucumber. The values are means of three replicates \pm standard error. An increase in phenolic contents is observed as the values are significantly different in comparison with control using the Duncan's Multiple Range Test at $\mathrm{P} \leq 0.05$ level.

Total proteins: Total proteins were increased at all the concentrations of SA viz., $0.01 \mathrm{mM}, 0.1 \mathrm{mM}, 1 \mathrm{mM}$ and 10 $\mathrm{mM}$ as compared to control (Fig. 2). Maximum protein contents were observed in plants treated with SA at two concentrations viz., $1 \mathrm{mM}$ and $10 \mathrm{mM}$. The protein contents were also increased in virus inoculated plants. SA applied at $10 \mathrm{mM}$ concentration followed by virus inoculation, the protein contents were significantly increased in plants i.e., $39.17 \mathrm{mg} / \mathrm{g}$ as compared to the plants where only SA was applied i.e., $28 \mathrm{mg} / \mathrm{g}$. 


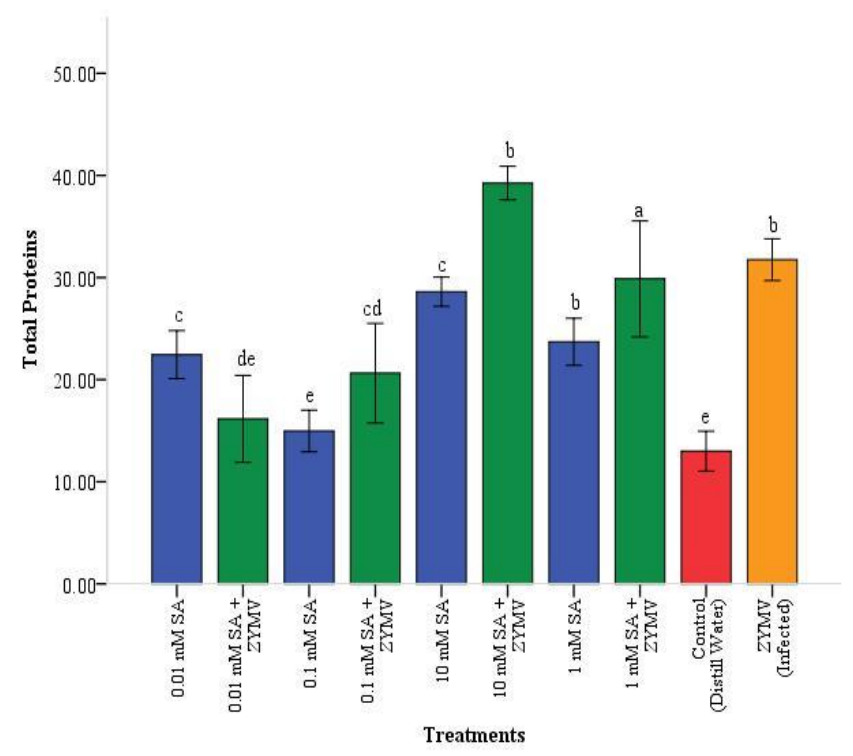

Figure 2. Effect of SA and ZYMV infection on total protein contents ( $\mathrm{mg} / \mathrm{g}$ fresh wt.) of cucumber. The values are means of three replicates \pm standard error. An increase in total proteins is observed as the values are significantly different in comparison with control using the Duncan's Multiple Range Test at $P \leq 0.05$ level.

\section{DISCUSSION}

In our research trial for the evaluation of cucumber germplasm, out of twenty different varieties/ lines only one variety Beit alpha showed resistant response against ZYMV in both the controlled and field conditions. Whereas 8 varieties/ lines in control and three varieties in field condition were appeared to be moderately resistant against ZYMV. Rest of the varieties showed susceptible and highly susceptible response. This means that there is scarcity of genetic resistance in cucumber against ZYMV because in cucurbit crops, the resistance against ZYMV is recessively inherited (Provvidenti, 1993). There are two sources of resistance against ZYMV, one of which is temperature dependent and other is not temperature dependent and show high level of resistance against ZYMV (Xu et al., 2004). So in our evaluation the varieties showed non viral race specific and temperature dependent resistance which showed the variability in the response of moderately resistant and susceptibility against ZYMV under controlled and field conditions. Disease severity percentage and virus titre were different in controlled and field condition of different varieties like G-227 which was susceptible in controlled condition while appeared to be highly susceptible in the field. Similarly Local khera and Baran-180 in controlled condition were moderately resistant while these varieties were susceptible in field condition; this difference may be appeared due to a-biotic stresses i.e. environmental conditions and virus vector or alternate host.

Different scientists also identified the resistant lines by evaluating the different accessions against ZYMV under controlled and field conditions. Only few accessions were recognized to have resistant genes. Pitrat and Lecoq (1984) identified dominant genes that have resistance against ZYMV in PI 414723 accession. Later on Anagnostou et al. (2000) also recognized the resistant genes from the same accession PI 414723 which have numerous resistances to ZYMV, WMV, PRSV and powdery mildew. Similarly, Wehner et al. (2004) found resistance against ZYMV in PI 595203 accession that was inoculated with ZYMV and did not show any symptoms and no virus was found through ELISA, while accessions 9811 and 98R have severe systemic mosaic symptoms and distorted leaves. Ling and Levi (2007) found only three accessions (PI 381825, PI 381831, and PI 381834) to be resistant against ZYMV. This means that genetic resistance against ZYMV in cucurbits in general and particularly in cucumber is very rare. We also identified only one variety which has showed the resistance against ZYMV under both field and controlled conditions. The variety which performed well during screening under field and controlled conditions would be better option for the selection in breeding program.

As there was scarcity of genetic resistance observed in cucumber against ZYMV therefore some other strategies should be opted for the integrated disease management. For this purpose an idea of induction of resistance ahead of pathogen attack by exogenously application of salicylic acid was employed. It has been reported that SA act as one of the signal producing mechanism that induce the resistance against virus infection (Radwan et al., 2007). In plant defense system, salicylic acid involved as a major signal molecule. In our work many changes were observed in morphological and metabolic processes in cucumber leaves and these changes were related with the production of secondary metabolites. The virus inoculated plants showed symptoms when SA was applied even at low concentrations of $0.01 \mathrm{mM}, 0.1 \mathrm{mM}$ and $1 \mathrm{mM}$ and virus titre was decreased gradually whereas at the concentration of $10 \mathrm{mM} \mathrm{SA}$, the symptoms were not appeared and virus was not detected through ELISA. Our results demonstrated that the application of SA 3 days before inoculation of ZYMV in cucumber leaves prevented the appearance of symptoms and also reduced the virus concentration. Exogenous application increased the phenolic and pathogenesis related protein contents which inhibited the virus replication and movement which resulted in the suppression of viral symptoms. The $0.01 \mathrm{mM}$ and $0.1 \mathrm{mM} \mathrm{SA}$ concentrations were found to be insufficient for inducing disease resistance. SA at $1 \mathrm{mM}$ concentration almost reduced the disease as compared to control. However, plant did not show any symptom when SA applied at $10 \mathrm{mM}$ concentration and virus titre was found to be 0.08 . Luo et al. (2011) reported 
that CMV infected arabidopsis leaves pre-treated with 0.1 $\mathrm{mM} \mathrm{SA}$ and $0.06 \mathrm{mM}$ jasmonic acid showed lighter symptoms as compared to the control. Esmailzadeh et al. (2008) observed similar results of SA as he demonstrated that when SA applied at $200 \mu \mathrm{M}$, resistance was not induced against tomato stem canker however when SA sprayed at 400 $\mu \mathrm{M}$, disease index significantly reduced as compared with infected control. Mayers et al. (2005) studied that when Salicylic acid (SA) applied, it induced the resistance against the Cucumber mosaic virus (CMV) in tobacco plants inducing the signal transduction pathway which inhibited the systemic virus movement. Elbadry et al. (2006) reported that endogenous application of SA produce the systemic resistances against BYMV in faba bean plants, our results also showed the enhanced resistance response against ZYMV in cucumber. Naylor et al. (1998) support our results where virus inoculated in tobacco plants after application of SA, the replication of Tobacco mosaic virus (TMV) was inhibited, he proposed that SA could induce inhibition of long distance viral movement and interferes with virus exit from the leaf. Furthermore, transduction defensive signal pathway induced resistance sensitive to inhibition by salicylhydroxamic acid. In healthy plants antibiotic occur constitutively as chemical barriers against pathogens. Phenolic compounds play important role as antibiotic that produced in the form of secondary metabolites from the shikimate-phenylpropanoidsflavonoids pathways. These phenolic compounds protect the host plant by killing the potential pathogens (Lattanzio et al., 2006). When pathogens attack tolerance or resistance mechanisms enable the plant to survive. In the analysis of phenolic contents in response of SA application, the phenolic contents level increased with the increase of SA concentration i.e., at $10 \mathrm{mM}$ SA concentration maximum phenolic compounds were produced and cucumber plant did not show any symptoms and virus was also not detected by ELISA as compared to other low concentrations of SA. Our results are in line with Matern and Kneusal (1988), they expressed that at the first stage of defense the growth of the pathogens restricted when phenols accumulate at infection site. Vimala and Suriachandraselvan (2009) reported that when SA applied through different ways alone, before inoculation, induced the resistance in Okra plants against powdery mildew caused by Erysiphe cichoracearum and produced the defense biochemical compound such as phenols and enzymes. Meena et al. (2001) reported that in groundnut plant exogenous application of salicylic acid before inoculation of Cercosporidium personatum increased the phenolic contents. Biotic and abiotic elicitors accumulate these phenolics contents in plants at the site of infection as response of hostpathogen interactions (Farkas and Kiraly, 1962).

Our results agree with Loon (1989) who reported that when various factors such as environmental stresses and necrotizing infection caused by any pathogens as response, plants synthesize sets of specific proteins known as pathogenesis related proteins (PRs). The PRs have typical physicochemical properties that enable the plants to protect against proteolytic cleavage and they survive in the harsh environments. Our work showed that total soluble protein contents were increased in inoculated and treated with SA plants as compared to control, while Devi et al. (2012) demonstrated that total protein contents were increased in inoculated plants than healthy plants and observed protein contents in healthy plants were $34 \mu \mathrm{g} \mathrm{g-}{ }^{1}$ while virus inoculated plants showed different level of protein contents 36 to59 $\mu \mathrm{g} \mathrm{g-}{ }^{1}$. Ashfaq et al. (2010) also observed that when viral pathogen attacked on Urdbean (Vigna mungo L.) plant then total proteins were increased due to viral proteins. Total soluble protein contents were increased in cucumber plants when salicylic acid applied at different concentration. Popova et al. (2003) reported that when barley seedling treated with low concentration of SA, protein contents level was not increased. Our results also showed that total protein contents were not increased significantly when SA applied at $0.01 \mathrm{mM}$ and $0.1 \mathrm{mM}$ concentration while maximum protein contents were observed when SA applied at $1 \mathrm{mM}$ and $10 \mathrm{mM}$ concentration as compared to control. SA treatments induced accumulation of defense-related proteins (Clarke et al., 1998). The results of this study also indicate that, when salicylic acid applied before virus inoculation, the defense genes were activated and produced the pathogenesis-related proteins and when inoculated with virus, the PR protein suppressed the viral protein i.e. the movement and replication of virus. Loon et al. (1994) reported that, anti pathogenic like character present in some pathogenesis-related proteins (PRs). In transgenic plants expression of individual PRs can lead to reduce the growth of pathogen and expression of symptom (Ryals et al., 1994). Our results are in line with the findings that the application of SA resulted in the production of (PR) protein that induced resistance against ZYMV. Zechmann et al. (2003) found that SA induced the resistance against TMV and accumulate the PR protein in tobacco plants. Resistance produced against ZYMV infection by formation of new protein and accumulation of PR protein. This indicated that formation of new poly-peptides or pathogeneses related protein produced the resistance in cucumber against ZYMV.

Conclusion: It is concluded that an exogenous application of SA could offer a good source for the management of ZYMV by inducing resistance in cucumber.

Acknowledgements: The study was funded by Directorate of Research and External Linkages, Bahauddin Zakariya University, Multan, Pakistan. This manuscript is a part of M.Sc. (Hons.) thesis of Mr. Muhammad Ejaz-ul-Haq, submitted to Department of Plant Pathology, Bahauddin Zakariya University, Multan, Pakistan. We are feeling exceedingly indebted to Agdia, Inc. USA; for showing 
compassionate cooperation in providing antibodies for ELISA.

\section{REFERENCES}

Anagnostou, K., M. Jahn and R.P. Treves. 2000. Inheritance and linkage analysis of resistance aganist Zucchini yellow mosaic virus, Watermelon mosaic virus, Papaya ringspot virus. Euphytica 116: 265-270.

Anand, A.S., R. Uppalapati, C.M. Ryu, S.N. Allen, L. Kang,Y. Tang and S . Mysore. 2008. Salicylic acid and systemic acquired resistance play a role in attenuating crown gall disease caused by Agrobacterium tumefaciens. Plant Physiol. 146: 703-715.

Anonymous. 2013. Agricultural Statistics of Pakistan 201011. Government of Pakistan, Ministry of Food, Agriculture and Livestock division. Economic wing Islamabad, Pakistan.

Ashfaq, M., U. Saeed, T. Mukhtar and M. I. ul Haq. 2015. First Report of Zucchini yellow mosaic virus in Ridge Gourd in Pakistan. Plant Dis. 99: P. 1870.

Ashfaq, M., M.A. Khan, N. Javed, S.M. Mughal, M. Shahid and S.T. Sahi. 2010. Effect of Urdbean leaf crinkle virus infection on total soluble protein and antioxidant enzymes in black gram plants. Pak. J. Bot. 42: 447-454.

Bradford, M.M. 1976. A rapid and sensitive method for the quantitation of microgram quantities of protein utilizing the principle of protein-dye binding. Anal. Biochem. 72: 248-254.

Bray, H.G. and W.V. Thorpe. 1954. Analysis of phenolic compounds of interest in metabolism. Methods Biochem. Anal. 1: 27-52.

Clark, M.E. and A.N. Adams. 1977. Characteristics of microplate methods of enzyme linked immunosorbent assay for detection of plant viruses. J. Gen. Virol. 34: 475-83.

Clarke, S.F., D.J. Buritt,P.E. Jameson and P.L. Guy. 1998. Influence of plant hormones on virus replication and pathogenesis-related proteins in Phaseolus vulgaris L. infected with white clover mosaic potexvirus. Physiol. Mol. Pl. Pathol. 53: 195-207.

Dodds, J.A., J.G. Lee, S.T. Nameth and F.F. Laemmlen. 1984. Aphid- and white fly transmitted cucurbits crops in viruses Imperial Valley, California. Phytopathol. 74: 221-225.

Devi, M. C. and Y. Radha. 2012. Induced biochemical changes in the CMV infected cucurbit plants. Ann. Bio. Res. 3:863-870.

Elbadry, M., R. M. Taha, K. A. Eldougdoug and H. G. Eldin. 2006. Induction of systemic resistance in faba bean (Vicia faba L.) to Bean Yellow Mosaic potyvirus (BYMV) via seed bacterization with plant growth promoting rhizobacteria. J. Pl. Dis. Prot. 113: 51-247.
Esmailzadeh, M., M. J. Soleimani and H. Rouhani. 2008. Exogenous applications of salicylic acid for inducing systemic acquired resistance against tomato stem canker disease. Bio. Sci. J. 6:1039-1044.

Farkas, G. and J. Kiraly. 1962. Role of phenolic compounds in the physiology of plant disease and disease resistance. J. Phytopathol. Z. 44 : 105-150.

Francki, R. I. B., D. W. Mossop and T. Hatta. 1979. Cucumber mosaic virus. CMI/AAB Descriptions of Plant Viruses, No. 213.

Halim, V. A., A. Vess, D. Scheel and S. Rosahl. 2006. The role of salicylic acid and jasmonic acid in pathogen defence. Pl. Biol. 8:307-313.

Huijsduijnen, R. A. M. V., S. W. Alblas and R. H. De. 1986. Induction by salicylic acid and pathogen-related proteins and resistance to Alfalfa mosaic virus in various plants species. J. Genet. Virol. 67: 2135-2143.

Lattanzio, V., V. M. T. Lattanzio and A. Cardinali. 2006. Role of phenolics in the resistance mechanisms of plants against fungal pathogens and insects. Phytochem. Adv. Res. 23-67.

Ling, K. S. and A. Levi. 2007. Sources of resistance to Zucchini yellow mosaic virus in Lagenaria siceraria germplasm. Hort Science 42:1124-1126.

Loon, V. L. C. 1989. Sterss proteins in infected plants. In: T. Kosuge and E. W. Nester (eds.), Plant-Microbe Interactions, Molecular and Genetic Perspectives. pp.198-237. MacGraw-Hill Publ. Comp., New York, USA.

Loon, V. L. C., W.S. Pierpoint, T. Boller and V. Conejero. 1994. Recommendations for naming plant pathogenesisrelated proteins. Pl. Mol. Biol. Rep. 12: 245-264.

Luo, Y., J. Shang, P. Zhao, D. Xi, S. Yuan and H. Lin. 2011. Application of jasmonic acid followed by salicylic acid inhibits Cucumber mosaic virus replication. Plant Pathol. J. 27:53-58.

Maleck, K., A. Levine, T. Eulgem, A. Morgan, J. Schmid and K. Lawton. 2000. The transcriptome of Arabidopsis thaliana during systemic acquired resistance. Nat. Genet. 26:403-409.

Matern, U. and R. E. Kneusal. 1988. Phenolic compounds in plant disease resistance. Phyto. Parasitica $16: 153-170$.

Mayers, C. N., K. C. Lee, C. A. Moore, S. M. Wong and J. P. Carr. 2005. Salicylic acid induced resistance to Cucumber mosaic virus in squash and Arabidopsis thaliana: Contrasting mechanisms of induction and antiviral action. Mol. Plant-Microbe Interact. 5: 428-434.

Meena, B., T. Marimuthu and R. Velazhahan. 2001. Salicylic acid induces systemic resistance in groundnut against late leaf spot caused by Cercosporidium personatum. J. Mycol. Pl. Pathol. 31: 139-145.

Miura, K. and Y. Tada. 2014. Regulation of water, salinity and cold stress responses by salicylic acid. Facul. of Agric. Kag Uni. Kag. Jap. 5: 4-12. 
Naylor, M., A. M. Murphy, J.Q. Berry and J.P. Carr. 1998. Salicylic acid can induce resistance to plant virus movement. Mol. Pl. Microbe Interact. 11: 860-868.

Pitrat, M. and H. Lecoq. 1984. Inheritance of Zucchini yellow mosaic virus-resistance in Cucumis melo. Euphytica 33:57-61.

Popova. L., E. Ananieva, V. Hristova, K. Christova, K. Georgieva, V. Alexieva and Z. H. Stoinova. 2003. Salicylic acid and methyl jasmonate protection on photosynthesis to paraquat oxidative stress, Bulg. J. Pl. Physiol. 133-152.

Provvidenti, R. 1993. Resistance to viral diseases of vegetables. Eds. By M. M. Kyle. Timber Press Portland, OR.

Radwan, D. E. M., K. A. Fayez, S. Y. Mahmoud, A. Hamad and G. Lu. 2007. Salicylic acid alleviates growth inhibition and oxidative stress caused by Zucchini yellow mosaic virus infection in Cucurbita pepo leaves. Physiol. Mol. Plant Pathol. 69: 172-181.

Ryals, J., S. Uknes and E. Ward. 1994. Systemic acquired resistance. Pl. Physiol. 104: 1109-1112.
Svoboda, J., L. Leisova-Svobodova and M. Amano. 2013. Evaluation of selected cucurbitaceous vegetables for resistance to Zucchini yellow mosaic virus. Plant Dis. 97:1316-1321.

Thakur, M. and B. S. Sohal. 2013. Role of elicitors in inducing resistance in plants against pathogen infection. Biochem. Art. ID 762412, 10.

Uta, V. R., J. Martin and J. D. Mueller. 2005. Evaluation of natural and synthetic stimulants of plant immunity by microarray technology. New Phytol. 165: 191-202.

Vimala, R. and M. Suriachandraselvan. 2009. Induced resistance in bhendi against powdery mildew by foliar application of salicylic acid. Biopest. J. 2: 111-114.

Xu, Y., D. Kang, Z. Shi, H. Shen and T. Wehner. 2004. Inheritance of resistance to Zucchini Yellow Mosaic Virus and Watermelon mosaic virus in watermelon. J. Hered. 95:498-502.

Zechmam, B., M. Muller and G. Zelling. 2003. Cytological modification in Zucchini yellow mosaic virus (ZYMV) infected styrian pumpkin plants. Arch. Virol. 148: 11191133. 